\title{
PERSEPSI MAHASISWA TERHADAP PEMBELAJARAN ONLINE DI IAKN TARUTUNG
}

\author{
Erika Christine Panggabean $^{1 *}$, Endang Juliati br Manullang ${ }^{1)}$, Jerry Stevan Sinambela ${ }^{1)}$ \\ ${ }^{1}$ Institut Agama Kristen Negeri Tarutung
}

\begin{abstract}
The purpose of this study was to determine student perceptions of online learning during the covid-19 pandemic. This descriptive research was conducted using a questionnaire technique that was distributed online to students at IAKN Tarutung with the help of google form. As many as 440 students from all study programs at IAKN Tarutung have played a role as respondents in this study. The results of the research that have been conducted show that as many as $42.3 \%$ choose the zoom meeting application which is often used by lecturers in the implementation of online learning. The form of online leaning conducted by lecturers by providing direct online explanations was chosen by students with a percentage of $74.8 \%$. In terms of using devices for online learning, 95.2\% of students use cellphones/smartphones. The main obstacle that students often face in the online learning process is slow internet access with a percentage of $31.1 \%$. And 418 students (95\%) of the total 440 students who had acted as respondents in this study preferred conventional learning (face-to-face) than online learning.
\end{abstract}

Keywords : online learning, student perseptions

\begin{abstract}
Abstrak
Tujuan dari penelitian ini untuk mengetahui persepsi mahasiswa terhadap pembelajaran online selama pandemic covid-19. Penelitian deskriptif ini dilakukan dengan teknik kuesioner yang disebar secara online kepada mahasiswa di IAKN Tarutung dengan bantuan google form. Sebanyak 440 mahasiswa dari semua program studi yang ada di IAKN Tarutung telah berperan menjadi responden penelitian ini. Hasil penelitian yang telah dilakukan menunjukkan bahwa sebanyak $42.3 \%$ memilih aplikasi zoom meeting yang sering digunakan oleh dosen dalam pelaksanaan perkuliahan online. Bentuk perkuliahan online yang dilakukan oleh dosen dengan cara memberikan penjelasan langsung secara online dipilih mahasiswa dengan persentase sebesar $74,8 \%$. Dalam hal penggunaan perangkat untuk pembelajaran online, sebanyak 95,2\% mahasiswa menggunakan handphone/smartphone. Kendala utama yang sering dihadapi mahasiswa dalam proses pembelajaran online adalah akses internet yang lambat dengan persentase sebesar $31,1 \%$. Dan 418 orang (95\%) mahasiswa dari total 440 mahasiswa yang telah berperan sebagai responden dalam penelitian ini lebih menyukai perkuliahan secara konvensional (tatap muka) daripada perkuliahan online.
\end{abstract}

Kata kunci : pembelajaran online, persepsi mahasiswa

81 | Korespondensi mengenai artikel dapat dilakukan kepada:

Erika Christine Panggabean, Institut Agama Kristen Negeri Tarutung, Jl. Raya Tarutung-Siborong-borong KM 11

Silangkitang, Kec. Sipoholon.

Email: erika.panggabean@gmail.com 


\section{PENDAHULUAN}

Awal tahun 2020, tepatnya bulan Maret 2020, Indonesia dilanda musibah Covid19 atau lebih dikenal dengan Corona virus. Kasus positif Covid-19 di Indonesia pertama kali dideteksi pada 2 Maret 2020, ketika dua orang terkonfirmasi tertular dari seorang warga Negara Jepang. Pada 9 April, pandemik sudah menyebar ke 34 provinsi dengan Jawa Timur, DKI Jakarta, dan Sulawesi Selatan sebagai provinsi paling terpapar (Kompas, 2020). Sejak saat itu, Pemerintah menghimbau agar beberapa wilayah memberlakukan pembatasansosial berskala besar (PSBB). Dampak dari pandemi Covid-19 ini sangat berpengaruh di berbagai sektor mulai dari sektor kesehatan, pendidikan, ekonomi bahkan pelayanan publik.

Kebijakan yang diambil oleh pemerintah Indonesia dengan meliburkan seluruh aktivitas pendidikan, membuat pemerintah dan lembaga terkait harus menghadirkan alternatif proses pendidikan bagi peserta didik maupun mahasiswa yang tidak bisa melaksanakan proses pendidikan pada lembaga pendidikan (Revisi SKB 4 Menteri PTM, Agustus 2020). Kebijakan di bidang pendidikan yang diambil oleh pemerintah terkait kasus Covid-19 yaitu pembelajaran daring/online bagi peserta didik (Surat Edaran Mendikbud Nomor 3 Tahun 2020)

Berkaitan dengan pandemi Covid-19 saat ini, Institut Agama Kristen Negeri (IAKN) Tarutung memutuskan untuk mengimplementasikan pembelajaran daring/online. Kebijakan ini dipilih demi memutus rantai penyebaran virus dan menjaga keselamatan mahasiswa dan dosen. Harus diakui juga bahwa kurangnya keterampilan menggunakan platform aplikasi pembelajaran daring dan juga tidak meratanya akses internet di berbagai daerah juga menjadi penghambat tersendiri bagi proses pembelajaran daring. Dengan demikian, pelatihan teknis dalam menggunakan berbagai macam platform aplikasi pembelajaran daring bagi mahasiswa dan dosen, dan pelatihan strategi pembelajaran daring bagi dosen dapat menjadi solusi (Lukman. 2020).

\section{METODE PENELITIAN}

Penelitian ini menggunakan metode survei dengan pendekatan deskriptif yang memiliki tujuan untuk menggambarkan keadaan atau fenomena yang terjadi (Arikunto, 2010). Penelitian ini akan mengkaji persepsi mahasiswa dalam melaksanakan 
perkuliahan daring/online. Responden penelitian adalah mahasiswa IAKN Tarutung yang aktif pada semester ganjil 2020/2021. Survei dilakukan secara daring melalui google forms. Sebanyak 440 mahasiswa telah berperan menjadi responden penelitian ini. Survei berlangsung selama 1 bulan pada tanggal 9 November 2020 sampai dengan 12 Desember 2020. Kuesioner penelitian ini terdiri dari 16 Pertanyaan dimana 15 pertanyaan menggunakan metode kuisioner tertutup dan 1 pertanyaan memberikan kebebasan untuk memberikan respon atau tanggapan.

\section{HASIL DAN PEMBAHASAN}

\section{Responden Penelitian}

Adapun responden penelitian ini berasal dari mahasiswa yang aktif pada semua program studi di IAKN Tarutung semester ganjil 2020/2021. Dimana 212 (48,3\%) mahasiswa merupakan mahasiswa program studi Pendidikan Agama Kristen, Program Studi Teologi 53 orang (12,1\%), Manajemen Pendidikan 39 orang (8,9\%), Pariwisata Budaya \& Keagamaan 38 orang (8,6\%), Sosiologi Agama 33 orang (7,5\%), Pendidikan Musik Gereja 24 orang (5,5\%), Pendidikan Kristen Anak Usia Dini (PKAUD) 22 orang (4,8\%), Pastoral Konseling 13 orang (3\%) dan Kepemimpinan Kristen 7 orang (1,6\%). Total keseluruhan responden adalah 440 orang dengan rincian 101 orang laki-laki dan 339 orang perempuan.

\section{Program Studi (Pilih Salah Satu) 439 tangepen}
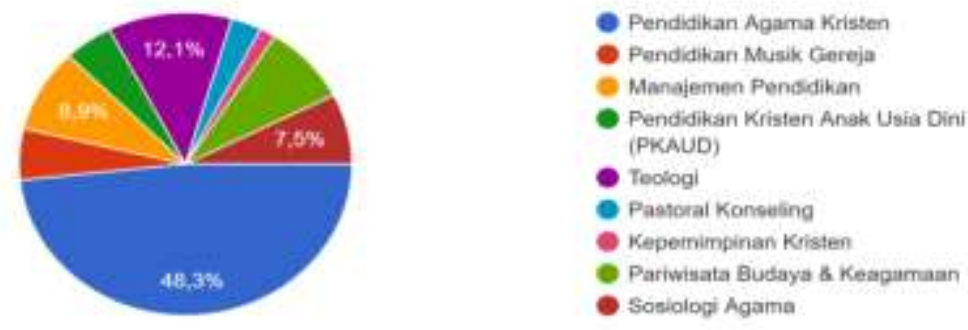

Gambar 1. Responden Penelitian

\section{Aspek Sarana dan Prasarana Pembelajaran Online}

Berdasarkan survei yang dilakukan diperoleh informasi tentang persepsi sarana dan prasarana yakni ketersediaan fasilitas yang dibutuhkan untuk melaksanakan 
perkuliahan online. Sebanyak 76,1\% mahasiswa menyatakan bahwa mereka melaksanakan pembelajaran online di rumah sendiri/orangtua. Media elektronik yang digunakan mahasiswa dalam pembelajaran online adalah handphone/smartphone sebanyak 95,2\% dan laptop/komputer sebanyak 4,8\%. Dari aspek penggunaan aplikasi, sebanyak 42,3\% mahasiswa menyatakan bahwa dosen menggunakan aplikasi zoom meeting untuk pelaksanaan pembelajaran online. Dan berdasarkan kondisi yang dialami oleh masing-masing mahasiswa, sebanyak 38,3\% mahasiswa lebih menyukai aplikasi whatsapp group untuk pembelajaran online.

1. Saudara melaksanakan Pembelajaran/Kuliah Online dimana? 439 tanggapan
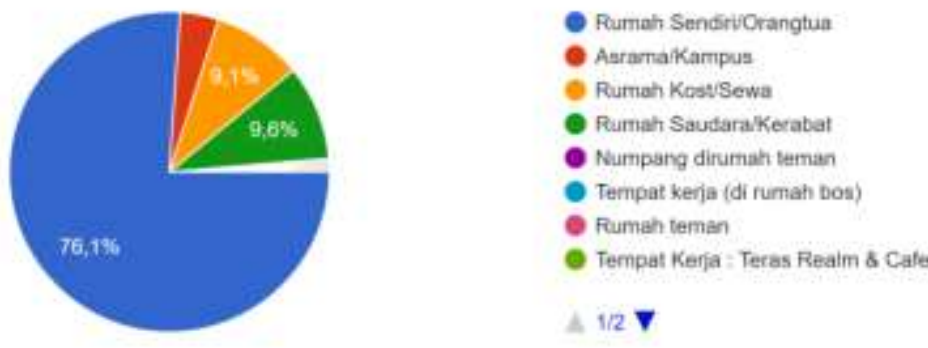

\section{Gambar 2. Tempat Pelaksanaan Pembelajaran Online}

Dari hasil survei yang dilakukan bahwa pembelajaran online dilakukan di rumah sendiri/orang tua, mengingat interaksi dan tidak adanya tatap muka bagi kegiatan perkulihan di kampus IAKN Tarutung, banyak mahasiswa memilih untuk kembali ke rumah masing masing dan mengikuti perkuliahan online di rumah masing masing terlihat dari hasil penelitian ini terdapat $76,1 \%$ mahasiswa melakukan daring di rumah masing-masing.

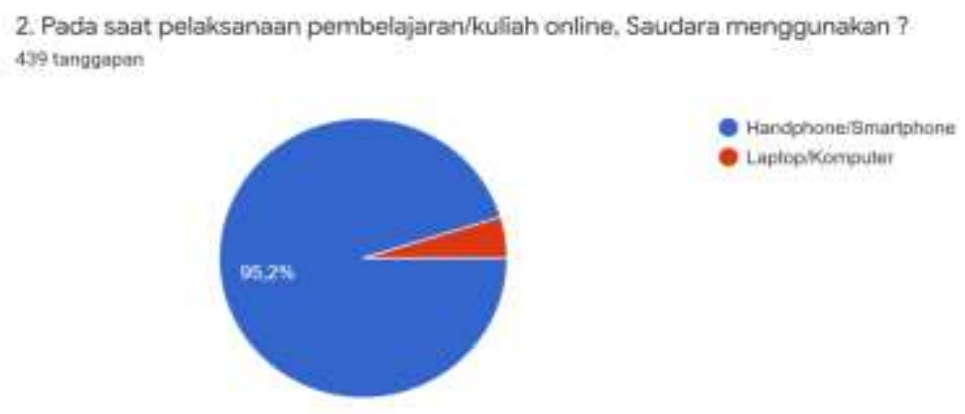

Gambar 3. Perangkat yang digunakan dalam Pelaksanaan Pembelajaran Online 
Mahasiswa menggunakan alternatif pilihan fasilitas yaitu laptop/komputer dan handphone/smartphone, dalam hal ini ada 95,2 \% mahasiswa IAKN Tarutung menggunakan handphone/smartphone dalam mengikuti pembelajaran daring. Dapat dikatakan fasilitas belajar yang dipakai oleh mahasiswa sangat terbatas dari segi penyajian mata kuliah karena handphone/smartphone tidak memfasilitasi semua bentuk bahan sajian dan dengan format akses yang terbatas, namun di sisi yang berbeda handphone/smartphone membantu mahasiswa dalam menghemat kuota internet, dalam hal ini dapat dikatakan bahwa dosen/pengajar harus menyesuaikan bahan ajar agar penyajian yang diberikan mudah di akses melalu smartphone.
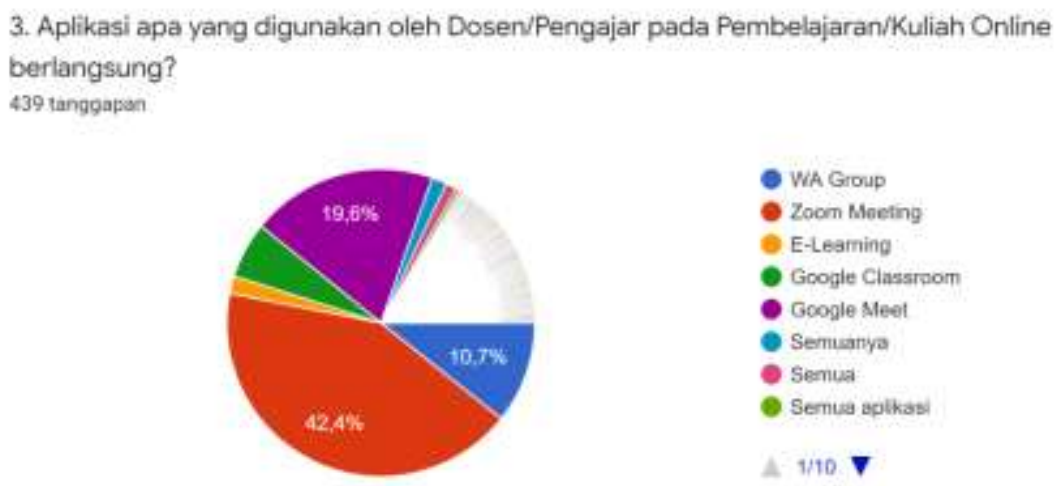

\section{Gambar 4. Aplikasi yang digunakan Pelaksanaan Pembelajaran Online}

Ada beberapa aplikasi yang digunakan dalam pembelajaran online baik itu aplikasi pembelajaran online yang di miliki oleh IAKN Tarutung berupa e-learning atau aplikasi yang tersedia baik google atau media belajar lain yang digunakan oleh dosen/pengajar sebagai akses untuk daring. Dan dari hasil penelitian didapat dosen/pengajar menggunakan zoom meeting sebanyak 42,4\%, google meet 19,6\% hal ini menjadi pilihan karena penjelasan mata kuliah mirip dengan pendekatan seperti tatap muka, namun terdapat juga yang memilih whatsapp group yaitu 10,7 \%.

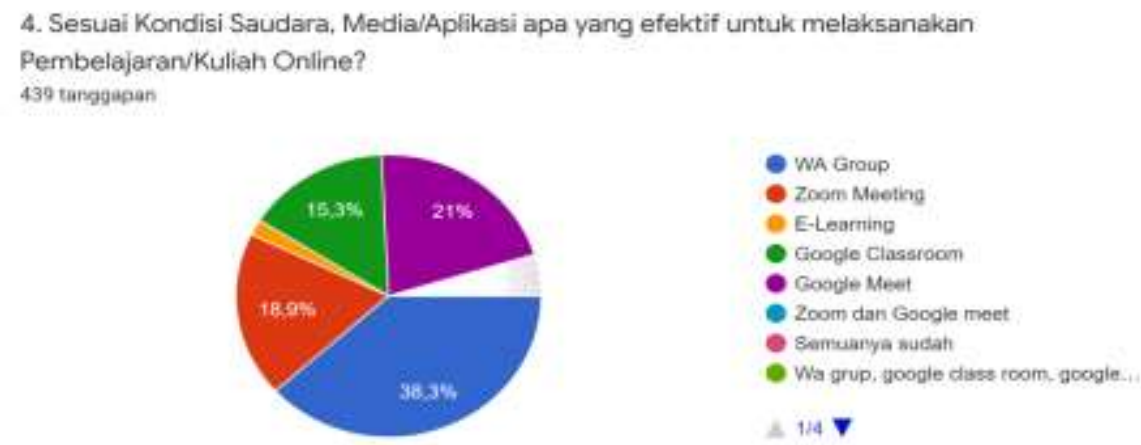

85 | Persepsi Mahasiswa Terhadap Pembelajaran Online, . . . . Erika, Endang, Jerry Jurnal Christian Humaniora| http://e-journal.iakntarutung.ac.id/index.php/humaniora 
Gambar 5. Aplikasi yang efektif digunakan Pelaksanaan Pembelajaran Online

Menindak lanjuti fasilitas daring yang digunakan oleh dosen/pengajar yang lebih banyak memilih menggunakan zoom meeting dan google meet, terdapat juga penggunaan fasilitas whatsapp group. Dan berdasarkan persepsi mahasiswa IAKN Tarutung didapatkan data bahwa hasil pembelajaran lebih efektif menggunakan whatsapp group sebanyak 38,3\% walaupun tidak sedikit juga jumlah responden yang menjawab kalau aplikasi di luar whatsapp group juga efektif, seperti google meet (21\%) dan zoom meeting $(18,9 \%)$. Whatsapp group dianggap merupakan pilihan yang lebih efektif untuk digunakan dalam perkuliahan daring mengingat masih belum maksimalnya fasilitas dan jaringan internet di daerah (Gusstiawan. 2020). Fitur-fitur yang terdapat pada whatsapp diantaranya chatting sebagai ruang untuk mengirim pesan antar sesama pengguna atau user, pada bagian attachment user dapat mengirimkan berbagai tipe file, dengan memanfaatkan gallery untuk menyisipkan gambar/foto, document untuk menyisipkan file dokumen tipe word, pdf, ppt dan lan-lain, audio menyisipkan file tipe $m p 3$ dan $m p 4$, location sebagai penanda posisi pengguna berada, contact untuk menyisipkan kontak. Selanjutnya selain pesan teks user juga dapat mengirimkan pesan suara (voice message) bahkan user dapat menelpon langsung user lainnya yang juga sedang online. Fitur-fitur tersebut tentu semakin menambah kemudahan dan kenyamanan berkomunikasi menggunakan whatsapp (Jumiatmoko, 2016). Dengan keadaan yang demikian, penggunaan zoom meeting dan google meet yang memerlukan kuota yang lebih besar dan jaringan internet yang lebih lancar dirasa lebih sulit jika dibandingkan dengan penggunaan whatsapp grup yang bisa bekerja maksimal sekalipun jaringan kurang bagus.

\section{Aspek Proses Belajar Mengajar secara Online}

Dilihat dari proses belajar mengajar, sebanyak 74,7\% mahasiswa memilih proses belajar mengajar yang diterapkan oleh dosen adalah dengan memberikan penjelasan langsung secara online. Dalam hal interaksi dalam proses pembelajaran online, sebanyak 64,9\% mahasiswa memilih interaksi dosen dengan mahasiswa bernilai baik. Sebanyak 57,9\% mahasiswa memilih bahwa mereka dapat memahami materi perkuliahan yang disampaikan oleh dosen. Dari segi kualitas materi kuliah online 
sebanyak $67,2 \%$ mahasiswa memilih materi perkuliahan yang disajikan berkualitas baik. Dalam pelaksanaan pembelajaran online, sebanyak 40,8\% mahasiswa memilih bahwa pembelajaran online tidak mudah.

\section{Bagaimana interaksi Dosen/Pengajar dan Mahasiswa menggunakan sistem perkuliahan daring/online? \\ 439 tanggapan}
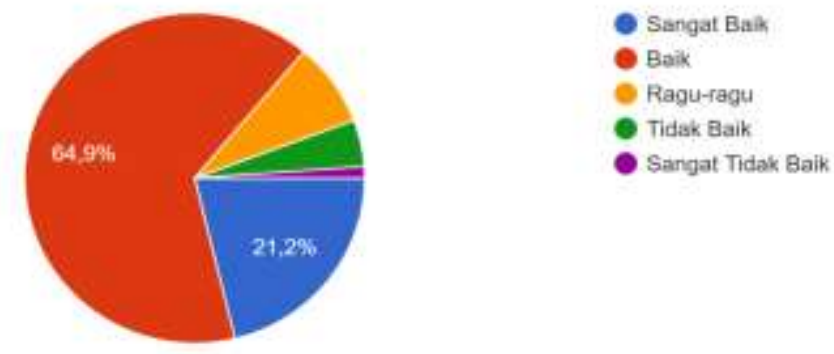

Gambar 6. Interaksi Dosen dan Mahasiswa

Ukuran keberhasilan perkuliahan daring/online dapat dilihat dari kualitas interaksi antara dosen/pengajar dalam rangka mencapai tujuan pembelajaran dan berdasarkan hasil yang dilakukan, dengan menggunakan fasilitas aplikasi yang ada secara online sebanyak 64,9\% mahasiswa menjawab bahwa interaksi yang ada antara dosen/pengajar dengan mahasiswa terjalin baik, dan yang selanjutnya sebanyak 21,2\% menjawab interaksi yang terjalin sangat baik. Dapat dikatakan bahwa interaksi antara dosen/pengajar dengan mahasiswa diperlukan dalam proses belajar mengajar untuk membangun komunikasi mengingat pertemuan tatap muka sudah tidak dilakukan dan diubah menjadi perkuliahan daring/online. Komunikasi atau interaksi yang baik akan memudahkan mahasiswa memahami mata kuliah yang sedang berlangsung secara daring (Erin \& Maharani, Anggita. 2018).

3. Apakah pada saat perkuliahan daring/online berlangsung, Saudara dapat memahami materi perkuliahaan yang disampaikan oleh Dosen/Pengajar dengan baik? 439 tangpapan
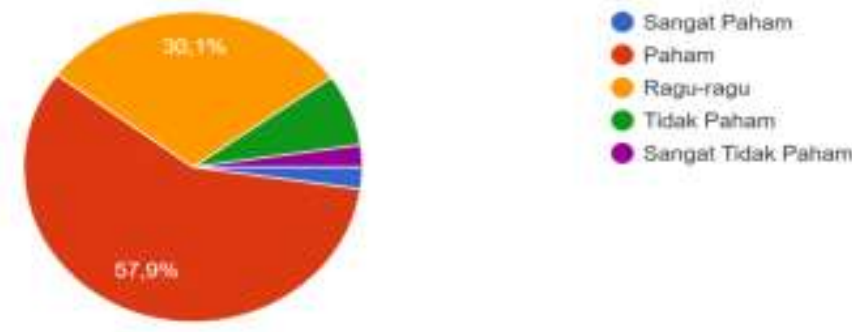

87 | Persepsi Mahasiswa Terhadap Pembelajaran Online, ... . Erika, Endang, Jerry Jurnal Christian Humaniora| http://e-journal.iakntarutung.ac.id/index.php/humaniora 


\section{Gambar 7. Pemahaman Mahasiswa terhadap materi yang disampaikan oleh Dosen}

Dalam rangka mencapai tujuan pembelajaran maka diharapkan interaksi yang terbangun dengan baik antara mahasiswa dengan dosen/pengajar akan menghasilkan pemahaman materi kuliah yang disampaikan oleh dosen (Gusstiawan. 2020). Dari penelitian yang sama terdapat beberapa kendala yang dihadapi dosen/pengajar dalam penyampaian materi kuliah, dan hal yang paling sering menjadi hambatan adalah jaringan internet yang buruk. Maka dosen/pengajar harus bisa selalu beradaptasi dengan keadaan, menyesuaikan bahan ajar dan bentuk penyajian mata kuliah agar tujuan belajar tercapai. Dan dari fasilitas yang digunakan dalam perkuliahan daring ini dapat dikatakan bahwa cara yang telah dilakukan sudah cukup efektif, karena dari hasil survei yang dilakukan tentang pemahaman materi kuliah ada 57,9\% yang menjawab bahwa mahasiswa paham dengan materi kuliah yang disampaikan.

\section{Bagaimana Kualitas Materi Perkuliahan yang disajikan dalam perkuliahan daring/online? 439 tanggapan}
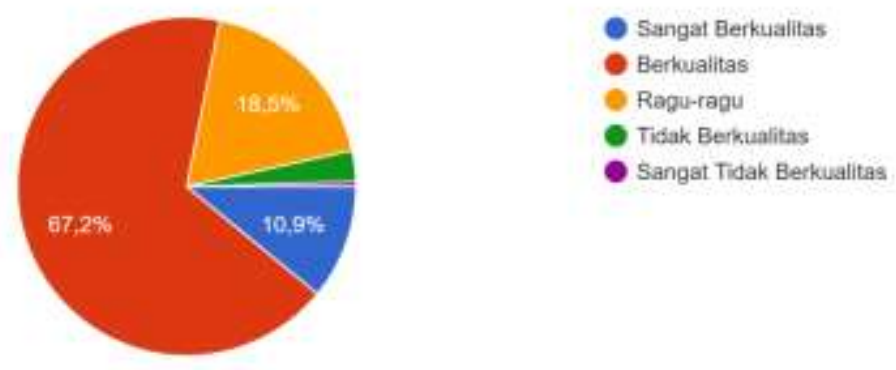

\section{Gambar 8. Kualitas Materi yang disajikan oleh Dosen}

Dalam tujuan pembelajaran memiliki tujuan agar mahasiswa memahami mata kuliah dari materi yang diberikan. Dan dalam rangka memberikan materi kuliah yang disajikan juga tetap memperhatikan kualitas materi mata kuliah. Mulai dari pemaparan materi, penjelasan materi, pemberian tugas baik individu ataupun kelompok, atau diskusi. Pada penelitian ini, persepsi terhadap materi kuliah yang diberikan dinilai berkualitas sebanyak 67,2\%. Dari hasil ini juga masih menjadi perhatian khusus bagi dosen/pengajar agar semakin memperhatikan kualitas materi kuliah dalam perkuliahan daring/online pada periode belajar berikutnya. 


\section{Menurut Saudara, seberapa mudah Perkuliahan Daring/Online dilakukan?} 439 tanggapan
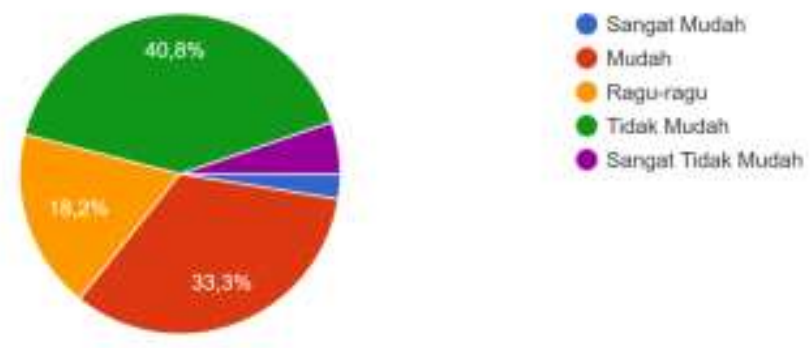

Gambar 9. Tingkat kemudahan Pelaksanaan pembelajaran online

Pembelajaran daring/online dilakukan karena seluruh dunia sedang mengalami situasi pandemi covid-19, dunia pendidikan juga harus dapat menyesuaikan kebutuhan dalam rangka kelancaran kegiatan belajar mengajar, mulai dari aplikasi yang digunakan, kualitas materi kuliah dan mempelajari hambatan yang dihadapi dalam perkuliahan daring/online yang termasuk di dalamnya adalah kualitas jaringan internet dan terbatasnya kuota internet.

Dan dalam hal kemudahan pelaksanaan pembelajaran daring/online berdasarkan hasil penelitian sebanyak 40,8\% mahasiswa menilai tidak mudah untuk pelaksanaannya, dan sebanyak 33,3\% menjawab mudah. Sejumlah 40,8\% hasil penelitian yang dilakukan termasuk angka yang perlu diperhatikan karena jika mahasiswa memiliki persepsi perkuliahan daring tidak mudah maka sangat besar kemungkinan tujuan belajar juga tidak akan terealisasi.

6. Bagaimana kesan Saudara terkait Perkuliahan Daring/Online 4,39 tanggapan
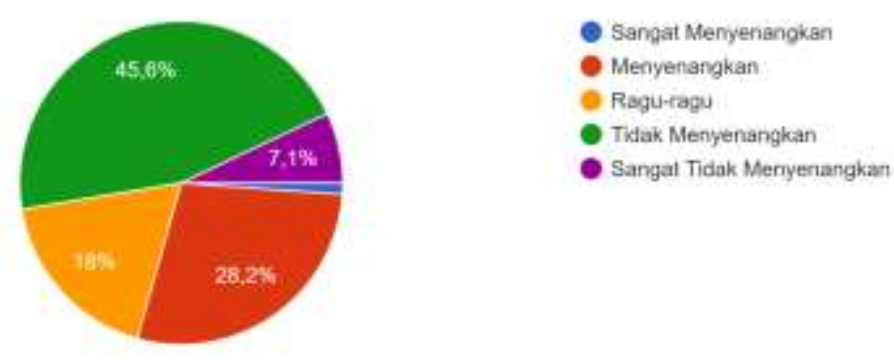

Gambar 10. Kesan yang dialami mahasiswa dalam pelaksanaan pembelajaran online 
Di Indonesia pelaksaan pembelajaran daring/online dimulai dari bulan Maret 2020 semenjak terdeteksinya 2 (dua) warga negara jepang terinfeksi covid-19, dapat dikatakan semua berdampak mulai dari perekonomian, sosial, kegiatan ibadah, pariwisata termasuk juga dunia pendidikan merasakan langsung efek perubahan besar. Yang paling terlihat nyata adalah perkuliahan tatap muka menjadi perkuliahan daring/online. Dan dalam pelaksanaan perkuliahan daring/online dengan semua fasilitas dan persiapan pembelajaran tetap juga dirasakan hambatan dan ketidakpuasan dalam perubahan ini, terbukti dari hasil penelitian yang dilakukan ada sebanyak 45,6\% mahasiswa menjawab bahwa pelaksanaan pembelajaran daring/online dinilai tidak menyenangkan, dan $28,2 \%$ menilai perkuliahan daring/online menyenangkan, ini termasuk angka yang rendah.

\section{Kendala utama mengikuti Perkuliahan Daring/Online 439 tanggapan}
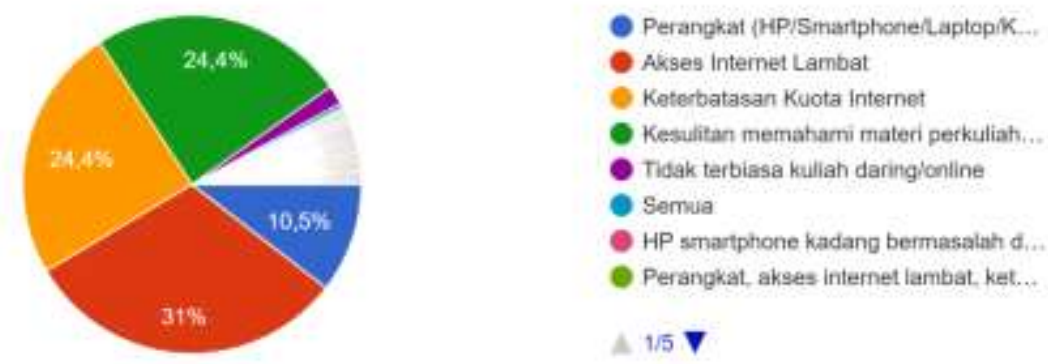

Gambar 11. Kendala utama dalam mengikuti pembelajaran online

Hasil penelitian menunjukkan bahwa kendala utama dalam pembelajaran daring/online berdasarkan tanggapan responden adalah akses internet sebanyak $31 \%$, jaringan internet yang masih belum bagus didaerah tempat tinggal responden untuk mendukung kegiatan perkuliahan daring yang lancar menjadi hambatan bagi $24,4 \%$ responden, interaksi dan komunikasi yang menjadi terganggu karena kuota internet yang terbatas juga memiliki persentase yang sama yaitu $24,4 \%$, masih menggunakan fasilitas handphone/smartphone karena terkadang bahan sajian mata kuliah tidak dapat tampil sesuai format juga termasuk kendala yang dihadapi dalam perkuliahan daring/online. Pada faktor lain, sebagian responden memiliki persepsi tambahan yaitu kejenuhan dalam perkuliahan daring/online. Kejenuhan tanpa interaksi sosial secara langsung ini menujukkan bahwa mahasiswa IAKN Tarutung merasakan kendala yang 
perlu ditemukan solusi cerdas untuk mendapatkan manfaat dari pembelajaran daring/online.

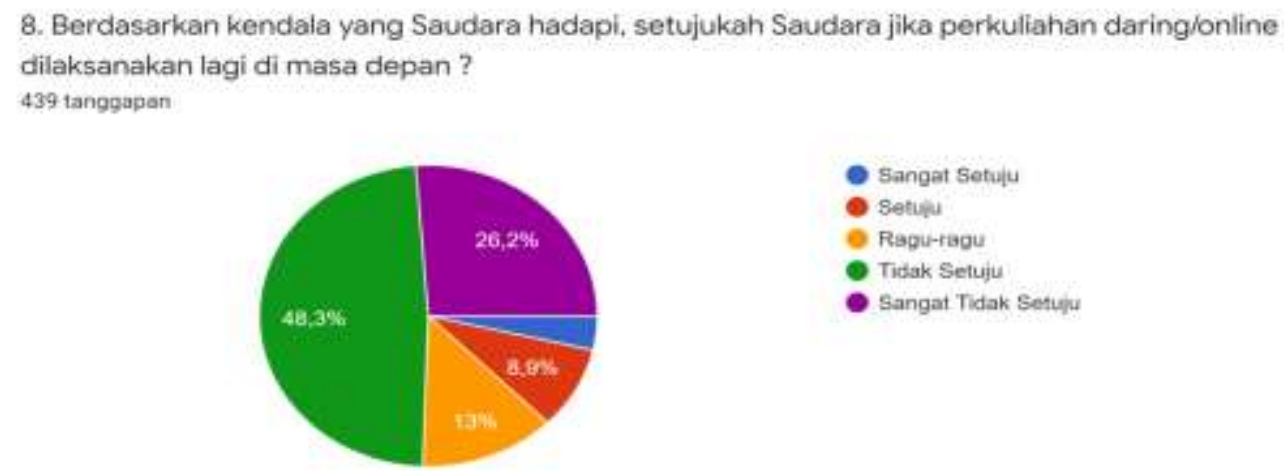

Gambar 12. Tanggapan mahasiswa terkaitan pembelajaran online dilaksanakan lagi di masa depan

Tidak ada sistem yang sempurrna untuk dilakukan termasuk perkuliahan daring/online yang dilakukan karena harus cepat beradaptasi dengan kebutuhan menjaga jarak dalam penyebaran covid-19 namun proses belajar mengajar di dunia pendidikan juga harus tetap berlangsung, sementara perkuliahan daring melibatkan banyak personal yang cara beradaptasi dalam perubahan sistem belajar pasti berbeda. Sistem yang terkadang masih gagap untuk diterima dan dijalani, termasuk dari hasil penelitian kali ini juga menunjukkan persepsi responden tentang kendala yang berdampak tidak tercapainya tujuan belajar. Dan dari kendala yang telah di alami oleh responden menjadikan persepsi bahwa 48,3\% responden tidak setuju dengan perkuliahan daring di masa depan dan 26,2\% menjawab sangat tidak setuju. Kendala yang bervariasi ini yang menjadikan responden lebih menginginkan perkuliahan tatap muka.

\section{Manakah yang Saudara lebih suka? 439 tanggapan}

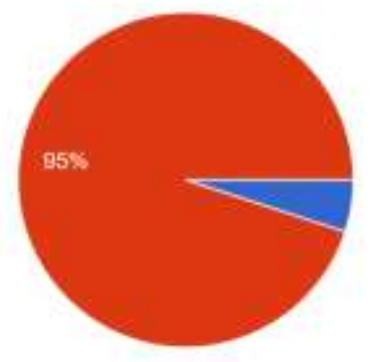




\section{Gambar 13. Tanggapan mahasiswa terkaitan model pembelajaran/perkuliahan}

Sistem belajar adalah salah satu pendukung dalam proses pembelajaran sebagai bentuk adaptasi mahasiswa dalam menghadapi perkuliahan daring/online. Dan bukan hanya fasilitas fisik (hardware dan software) saja yang menjadi perhatian, namun juga dari sisi mental mahasiswa dalam menjalani perkuliahan daring dengan segala hambatannya. Karena dari penelitian ini juga terdapat kejenuhan responden tanpa interaksi sosial dengan lingkungan kampus juga sebagai kendala. Sehingga dalam pertanyaan terakhir dipenelitian ini tentang tanggapan mahasiswa terkait model perkuliahan mengatakan persepsi $95 \%$ memilih perkuliahan konvensional atau tatap muka.

\section{KESIMPULAN DAN SARAN}

\section{Kesimpulan}

Dari hasil pengolahan data menunjukkan bahwa 440 orang mahasiswa IAKN Tarutung menilai bahwa beberapa metode perkuliahan online yang efektif yaitu dari sisi media yang digunakan terlihat dari media pembelajaran yang dipilih secara online yaitu google meet dan zoom meeting, sementara untuk pemilihan whatsapp group sebagai media lebih disukai karena telah digunakan sehari-hari dan ketika jaringan internet buruk pun masih dapat berinteraksi di perkuliahan. Untuk bentuk perkuliahan yang telah dilakukan juga dapat diikuti mulai dari penjelasan materi kuliah, tugas individu dan kelompok, referensi video dan diskusi. Kegiatan belajar yang baik jika diberikan metode perkuliahaan yang tepat dan dalam hal ini penelitian menghasilkan bahwa memberikan penjelasan langsung secara online akan lebih efektif, karena interaksi dan komunikasi yang efektif dan efisien juga sangat dibutuhkan. Dari hasil ini juga didapati bahwa mahasiswa lebih menyukai perkuliahan tatap muka namun karena adanya perubahan mekanisme perkuliahan dalam bentuk daring/online maka mahasiswa harus bisa beradaptasi dengan perubahan cara belajar di kondisi pandemi covid-19.

\section{Saran}

Kegiatan perkuliahan daring/online akan diperlukan adaptasi yang berkelanjutan diantara visi agar tujuan belajar tercapai, termasuk di dalamnya perkembangan teknologi dan fitur-fitur terbaru demi kelengakpan software mendukung kegiatan 
belajar. Kondisi ini menuntut mahasiswa agar terus belajar dan membutuhkan waktu dalam menguasai media pembelajaran yang ditentukan. Perkuliahan daring akan selalu identik dengan sarana belajar yang mendukung, salah satunya adalah e-learning yang digunakan di kampus dalam hal ini IAKN Tarutung.

Perkuliahan daring juga menuntut dosen/pengajar untuk menemukan cara belajar yang komunikatif, efisien dan efektif demi tujuan belajar yang tercapai diantara kendala mahasiswa yaitu fasilitas belajar dan jaringan internet yang buruk. Dosen/pengajar diharapkan dapat memberikan motivasi belajar dalam rangka meningkatkan kualitas mutu lulusan yang menjadi visi dan tujuan IAKN Tarutung.

\section{DAFTAR PUSTAKA}

Arikunto, S. (2010). Prosedur Penelitian : Suatu Pendekatan Praktik (Edisi Revisi). Rineka Cipta.

Erin \& Maharani, Anggita. (2018). Persepsi Mahasiswa Pendidikan Matematika Terhadap Perkuliahan Online. Mosharafa: Jurnal Pendidikan Matematika, 7(3), 337-344.

Hadi, Lukman. (2020). Persepsi Mahasiswa Terhadap Pembelajaran Daring Di Masa Pandemik Covid-19. Jurnal Zarah, 8(2), 56-61.

Jumiatmoko. (2016). Whatsapp Messenger Dalam Tinjauan Manfaat dan adab. Jurnal Wahana Akademika Volume 3 Nomor 1, April 2016.

Maulana, Hutomo Atman \& Hamidi, Muhammad. (2020). Persepsi Mahasiswa terhadap Pembelajaran Daring pada Mata Kuliah Praktik di Pendidikan Vokasi. Equilibrium: Jurnal Pendidikan, 8(2), 224-231.

Raimanu, Gusstiawan. (2020). Persepsi Mahasiswa Terhadap Implementasi Pembelajaran Daring Pada Masa Pandemi Covid-19 (Studi Pada Mahasiswa Fakultas Ekonomi Universitas Sintuwu Maroso). Jurnal EKOMEN, 19(2), 1-9.

Ratnawati, Dwi \& Vivianti. (2020). Persepsi Mahasiswa Terhadap Pembelajaran Daring pada Matakuliah Praktik Aplikasi Teknologi Informasi. Jurnal Edukasi Elektro, 4(2), 110-120.

Revisi SKB 4 Menteri PTM, Agustus 2020 tentang panduan penyelenggaraan pembelajaran pada tahun ajaran 2020/2021 dan tahun akademik 2020/2021 di masa pandemic coronavirus disease 2019 (Covid-19).

Saifuddin, Much. Fuad. (2017). E-Learning Dalam Persepsi Mahasiswa. Varia Pendidikan, 29(2), 102-109.

Sugiyono. (2010). Metode Penelitian Kuantitatif, Kualitatif dan R\&D. Bandung: Alfabeta.

Surat Edaran Mendikbud Nomor 3 Tahun 2020 tentang kebijakan pemerintah di bidang pendidikan terkait kasus Covid-19. 